\title{
Development of self compacting concrete with various mineral admixtures
}

\author{
B. H. Venkataram Pai ${ }^{1}$, Maitreyee Nandy ${ }^{2}$, A. Krishnamoorthy ${ }^{1}$, Pradip Kumar Sarkar ${ }^{3}$, \\ C. Pramukh Ganapathy ${ }^{1}$, Philip George ${ }^{1}$
}

${ }^{1}$ Dept. of Civil Engg.,Manipal Institute of Technology, Manipal, India

${ }^{2}$ Chemical Sciences Division, Saha Institute of Nuclear Physics, Kolkata, India

${ }^{3}$ Manipal Centre for Natural Sciences, Manipal, India

\section{Email address:}

pai.bhv@gmail.com (B. H. Venkataram Pai),mnandy07@gmail.com (M. Nandy),moorthy.mit@manipal.edu (A. Krishnamoorthy), pksarkar02@gmail.com (P. K. Sarkar),pramukh.ganapathy@hotmail.com (C. P. Ganapathy), philipgeo17@gmail.com (P. George)

\section{To cite this article:}

B. H. Venkataram Pai, Maitreyee Nandy, A. Krishnamoorthy, Pradip Kumar Sarkar, C. Pramukh Ganapathy, Philip George. Development of Self Compacting Concrete with Various Mineral Admixtures. American Journal of Civil Engineering. Vol. 2, No. 3, 2014 , pp. $96-101$. doi: 10.11648/j.ajce.20140203.16

\begin{abstract}
Self- Compacting concrete (SCC) is a special type of concrete that is able to flow and compact under its own weight and can occupy all the spaces in the form without any vibration effect, and at the same time cohesive enough to be handled without bleeding or segregation. The required compaction properties are achieved by adding super-plasticizers and mineral admixtures such as fly ash, rice husk ash, silica fume, etc. The utilization of these treated industrial by-products as cement replacement will not only help to achieve an economical SCC mix, but it is envisaged that it may improve the microstructure and consequently the durability of concrete. This provides solution to disposal problems and other environmental pollution issues created by these otherwise waste products. This paper presents the results of an experimental study aimed at producing SCC mixes of M25 grade by using the Modified Nan Su method, incorporating five mineral admixtures, viz., Fly Ash, Blast Furnace Slag (GGBS), Silica Fumes, Rice Husk Ash, and Shell Lime powder as supplementary cementing materials. Also, this paper gives the comparison of these SCC mixes in terms of their properties like compressive, split tensile, and flexural strengths. The fresh concrete properties are also included in the study.
\end{abstract}

Keywords: Self-Compacting Concrete, Fly Ash, Rice Husk Ash, GGBS, Shell Lime Powder, Silica Fume

\section{Introduction}

SCC was first developed in Japan in the late 1980s as a concrete that can flow through congested reinforcing bars with elimination of additional compaction and without undergoing any significant segregation and bleeding under its own weight. SCC has gained wide use in many countries for different applications and structural configurations. The use of SCC has many advantages such as: faster construction, eliminating the need for vibration, reducing the noise pollution, improving durability and the filling capacity of highly congested structural members, better surface finishes and also safe working environment $[1,2]$.

SCC consists of the same components as the conventionally vibrated concrete, which are cement, aggregates and water, with the addition of chemical and mineral admixtures in different proportions. While designing SCC the volume of the coarse aggregate should be restricted so as to avoid the possibility of blockage on passing through spaces between steel bars. This reduction necessitates the use of a higher volume of cement which results in a greater temperature rise and increase in the cost of construction. Thus incorporating high volumes of mineral admixtures such as fly ash, rice husk ash, GGBS, silica fume etc. can make it cost effective. However, the durability of such SCC needs to be proven [3]. For concrete to be self-compacting it should have filling ability, passing ability and resistance against segregation. These properties are obtained by limiting the coarse aggregate content and using lower water-powder ratio together with super plasticizers [4].

Fly ash is a beneficial mineral admixture for concrete. Research shows that adding fly ash to normal concrete, as a partial replacement of cement (less than 35\%), will benefit both the fresh and hardened states [5]. If concrete is mixed with ground granulated blast furnace slag as a partial 
replacement for Portland cement, it would provide environmental and economic benefits and the required workability, durability and strength necessary for the structures. The cementitious efficiency of ground granulated blast furnace slag (GGBS) at 28 days was tested at various replacement levels and concluded that it is possible to design GGBS concrete for a desired strength up to an optimum replacement percentage of 50\% [6]. From the experimental investigation on SCC containing silica fume it is clear that cement can be replaced with $15 \%$ silica fume effectively, thereby reducing the consumption of cement, which in turn reduces the cost [7]. Rice husk ash has been used as a highly reactive pozzolanic material to improve the microstructure of the interfacial transition zone between the cement paste and the aggregate in SCC. Research shows that the utilization of rice husk ash in SCC mix (less than 20\%) produced desired results and also provided an environment friendly disposal of agro-industry waste product [8]. The advantages of using shell lime powder are that it blends in the concrete mix easily and forms a very good cohesive mix. It also acts as a good viscosity modifier for fresh concrete paste. The research shows that utilization of shell lime powder less than $30 \%$ in concrete gives satisfactory results [9].

So far a mix design procedure to fix the ratio of all the ingredients in SCC is not standardized. No method specifies the grade of concrete in SCC except the Nan Su method. But the limitation of this method is that it does not provide required mix proportions for the grade which is less than M50. In this work, mix designing was carried out for M25 grade concrete, and the procedure is based on the modified Nan Su method [10].

\section{Experimental Program}

\subsection{Materials}

\subsubsection{Cement}

All through the experimental study, Ordinary Portland Cement conforming to IS: 8112 -1989 [11], was used. The physical and mechanical properties of the cement used are shown in Table 1.

Table 1. Properties of Cement.

\begin{tabular}{ll}
\hline Physical property & Results \\
\hline Fineness & $2946 \mathrm{~cm}^{2} / \mathrm{gm}$. \\
Normal Consistency & $30 \%$ \\
Vicat initial setting time (minutes) & 64 \\
Vicat final setting time (minutes) & 192 \\
Specific gravity & 3.10 \\
Compressive strength at 3-days & $23.86 \mathrm{MPa}$ \\
Compressive strength at 7-days & $37.01 \mathrm{MPa}$ \\
Compressive strength at 28-days & $45.73 \mathrm{MPa}$ \\
\hline
\end{tabular}

\subsubsection{Fly Ash}

Fly ash is a by-product obtained during the process of combustion of pulverized coal in electric power generating plants. Fly Ash has particles of diameter about $10-25 \mu \mathrm{m}$. The particles are smooth and spherical. This improves fluidity of the SCC mixture. Also, Fly Ash has pozzolanic properties where it reacts with calcium hydroxide, to produce calcium silicate hydrate, which is the product formed during hydration of cement. This helps in strength gain at later ages of curing and reduces heat of hydration which in turn reduces free shrinkage of concrete, resulting in a reduction of thermal shrinkage cracking. Fly ash also refines the pore structure of concrete and decreases its permeability, which has good implications on durability and long-term strength. The quality of slag is governed by IS: 3812-1 2003 [12]. Table 2 shows the properties of Fly Ash.

\subsubsection{Ground Granulated Blast Furnace Slag (GGBS)}

Ground granulated slag is a by- product obtained during the process of purification of iron ore. It is a non-metallic powder having chemical composition of silicates and aluminates of calcium and other bases. The chemical composition of GGBS is nearer to that of cement clinker. The performance of slag depends on the chemical composition and fineness of grinding. The quality of slag is governed by IS: 12089-1987 [13]. Table 2 shows the properties of GGBS.

\subsubsection{Silica Fume}

Silica fume is also called micro silica or condensed silica fume. It is generally used as artificial pozzolonic admixture in concrete. It is a product obtained by reduction of high purity quartz with coal in an electric arc furnace in the manufacture of silicon or ferrosilicon alloy. Condensed silica fume is essentially silicon dioxide (more than 90\%) which is present in non- crystalline form. It is extremely fine powder with particle size less than 1 micron and with an average diameter of about 0.1 micron, about 100 times smaller than average cement particles. The quality of silica fume is governed by IS $15388-2003$ [14]. Table 2 shows the properties of silica fume.

\subsubsection{Rice Husk Ash (RHA)}

Rice husk ash is a by- product obtained by burning rice husk by appropriate combustion technique. It is used in concrete as a supplementary cementitious material. The combustion period, chilling duration, and grinding process and duration are important factors that influence the property of RHA. It improves the microstructure of the interfacial transition zone between the cement paste and the aggregate[15]. Table 2 shows the properties of RHA.

\subsubsection{Shell Lime}

Molluscs like shell fish in the oceans have protective shells that contain $\mathrm{CaCO}_{3}$ or lime. This resource can be used as an alternative for the limestone deposits. Shell lime is obtained by burning a combination of shells and coal in a furnace. It has calcium oxide $(\mathrm{CaO})$ and has properties similar to cement [16]. The properties of shell lime are tabulated in Table 2 . 
Table 2. Properties of Mineral Admixtures.

\begin{tabular}{llcc}
\hline \multirow{2}{*}{ Materials } & \multicolumn{3}{c}{ Properties } \\
\cline { 2 - 4 } & Colour & Consistency (\%) & Sp. Gravity \\
\hline Fly Ash & Grey & 45 & 2.23 \\
GGBS & Dull white & 36 & 2.83 \\
Silica Fume & Light Blue & 116 & 2.14 \\
RHA & Dark Grey & 26 & 2.13 \\
Shell Lime & White & 49 & 3.09 \\
\hline
\end{tabular}

\subsubsection{Aggregates}

Locally available river sand of specific gravity 2.64, fineness modulus 2.91, and conforming to Zone II was used as fine aggregate. The crushed granite stone with a maximum size of $12 \mathrm{~mm}$, and specific gravity 2.65 was used as coarse aggregate. Both fine aggregate and coarse aggregate used conform to IS: 383-1970 [17].

\subsubsection{Super Plasticizer (SP)}

Super plasticizer (SP) is a chemical admixture which is used in concrete to increase the workability, with minimal use of water. The super plasticizer used in the present work is the commercially available brand, Cera Hyper plasticizer.

\subsubsection{Water}

Potable water was used for mixing and curing concrete.

\subsection{Mix Proportioning}

\subsubsection{Modified Nan Su Method}

The important parameter in SCC is the mix proportioning methodology. So far a proper mix design procedure to get the proportion of the ingredients in SCC is not standardized. No method specifies the grade of concrete in SCC except the Nan $\mathrm{Su}$ method. Unlike other proportioning methods like the Okamura and EFNARC methods, it gives an indication of the target strength that will be obtained after 28 days of curing. But the limitation of this method is, it does not give required mix proportions for normal grades (grades less than M50). Research shows that the cement content was not sufficient to attain the required strength for normal grades. So a number of trials are required to attain the target strength. To avoid the number of trials and to satisfy the requirement of strength and durability of the mix some modifications are made in the Nan Su method. Here, the mix designs were carried out for M25 grade concrete and are based on the modified Nan Su method [10]. The procedure of modified Nan Su method can be summarized in the following steps.

Step 1: Calculation of Coarse and Fine Aggregate Contents

The content of fine and coarse aggregates can be calculated by knowing packing factor (PF).

$$
\begin{gathered}
\mathrm{W}_{\mathrm{ca}}=\operatorname{PF} \mathrm{X} \mathrm{W}_{\mathrm{dc}} \mathrm{X}(1-\mathrm{S} / \mathrm{a}) \\
\mathrm{W}_{\mathrm{fa}}=\operatorname{PF} \mathrm{X} \mathrm{W}_{\mathrm{df}} \mathrm{X}(\mathrm{S} / \mathrm{a})
\end{gathered}
$$

Where $\mathrm{W}_{\mathrm{ca}}$ : content of coarse aggregates in $\mathrm{SCC}\left(\mathrm{kg} / \mathrm{m}^{3}\right)$; $\mathrm{W}_{\mathrm{fa}}$ : content of fine aggregates in $\mathrm{SCC}\left(\mathrm{kg} / \mathrm{m}^{3}\right) ; \mathrm{W}_{\mathrm{dc}}$ : bulk density of coarse aggregates in air $\left(\mathrm{kg} / \mathrm{m}^{3}\right) ; \mathrm{W}_{\mathrm{df}}$ : bulk density of fine aggregates in air $\left(\mathrm{kg} / \mathrm{m}^{3}\right)$; PF: packing factor, the ratio of mass of aggregates of tightly packed state in SCC to that of loosely packed state in air;S/a: volume ratio of fine aggregates to total aggregates $(50 \%-57 \%)$.

Step 2: Calculation of Cement Content

Generally, HPC or SCC used in Taiwan provides a compressive strength of $20 \mathrm{psi}(0.14 \mathrm{MPa}) / \mathrm{kg}$ cement. Since the quantity of cement is not enough for normal grades to gain the required strength, correction factors are introduced. Therefore the cement content to be used is:

$$
\mathrm{C}=\mathrm{C} . \mathrm{F}\left(\mathrm{f}_{\mathrm{c}}^{\prime} / 20\right)
$$

Where C: cement content $\left(\mathrm{kg} / \mathrm{m}^{3}\right)$; C.F: correction factor for cement; f'c: designed compressive strength (psi). [10]

The correction factor for M25 grade concrete is 2.02

Step 3: Calculation of Mixing Water Content Required by Cement

The content of mixing water required by cement can then be obtained by

$$
\mathrm{W}_{\mathrm{WC}}=\mathrm{CX}(\mathrm{W} / \mathrm{C})
$$

Where $\mathrm{W}_{\mathrm{WC}}$ : content of mixing water content required by cement $\left(\mathrm{kg} / \mathrm{m}^{3}\right) ; \mathrm{W} / \mathrm{C}$ : the water/cement ratio by weight, which can be determined by compressive strength.

Step 4: Calculation of Filler Contents

The volume of filler paste can be calculated as follows

$$
\mathrm{V}_{\mathrm{pf}}=1-\left(\mathrm{W}_{\mathrm{ca}} / 1000 \mathrm{G}_{\mathrm{ca}}\right)-\left(\mathrm{W}_{\mathrm{fa}} / 1000 \mathrm{G}_{\mathrm{fa}}\right)-\left(\mathrm{C} / 1000 \mathrm{G}_{\mathrm{C}}\right)-
$$

Amount of filler required,

$$
\mathrm{W}_{\mathrm{f}}=\mathrm{V}_{\mathrm{pf}} \mathrm{X} 1000 \times \mathrm{G}_{\mathrm{f}} /(1+\mathrm{W} /
$$

Where $\mathrm{G}_{\mathrm{ca}}$ : specific gravity of coarse aggregates; $\mathrm{G}_{\mathrm{fa}}$ : specific gravity of fine aggregates; $\mathrm{G}_{\mathrm{C}}$ : specific gravity of cement; $G_{w}$ : specific gravity of water; $G_{f}$ :specific gravity of filler material ; $\mathrm{V}_{\mathrm{a}}$ : air content in SCC (\%).

Mixing water content required by filler paste is,

$$
\mathrm{W}_{\mathrm{Wf}}=(\mathrm{W} / \mathrm{F}) \mathrm{W}_{\mathrm{f}}
$$

Step 5: Calculation of Mixing Water Content Needed in $\mathrm{SCC}$

The mixing water content required by $\mathrm{SCC}$ is the total amount of water needed for cement and filler in mixing. Therefore, it can be calculated as follows:

$$
\mathrm{W}_{\mathrm{W}}=\mathrm{W}_{\mathrm{WC}}+\mathrm{W}_{\mathrm{Wf}}
$$

Step 6: Calculation of SP Dosage

If the dosage of SP used is $\mathrm{n} \%$ of the amount of binders and its solid content is $\mathrm{m} \%$ then:

$$
\begin{aligned}
& \text { Dosage of SP used, } \mathrm{W}_{\mathrm{SP}}=\mathrm{n} \%\left(\mathrm{C}+\mathrm{W}_{\mathrm{f}}\right) \\
& \text { Water content in SP, } \mathrm{W}_{\mathrm{WSP}}=(1-\mathrm{m} \%) \mathrm{W}_{\mathrm{SP}}
\end{aligned}
$$

Based on the above method of mixture design the 
mixture constituents of SCC were achieved for design strength of M25. The mix constituents are listed in Table 3.

Table 3. Mix constituents of SCC mixes in $\mathrm{kg} / \mathrm{m}^{3}$.

\begin{tabular}{cccccc}
\hline $\begin{array}{c}\text { Mixture } \\
\text { Constituent }\end{array}$ & $\begin{array}{c}\text { Fly } \\
\text { Ash }\end{array}$ & GGBS & $\begin{array}{c}\text { Silica } \\
\text { Fume }\end{array}$ & RHA & $\begin{array}{c}\text { Shell } \\
\text { Lime }\end{array}$ \\
\hline Cement & 361 & 361 & 361 & 361 & 361 \\
Mineral Ad. & 110 & 148 & 70 & 120 & 147 \\
Coarse Agg. & 743 & 743 & 743 & 743 & 743 \\
Fine Agg. & 961 & 961 & 961 & 961 & 961 \\
Water & 199 & 203 & 232 & 182 & 223 \\
SP & 8.47 & 9.15 & 7.75 & 8.65 & 9.14 \\
\hline
\end{tabular}

\subsection{Acceptance Tests on SCC Mixes}

Once a satisfactory mix was arrived at, all the mixes were tested in the laboratory as per the EFNARC guidelines [18] to assess the property of the mix to qualify as SCC. T50 Slump flow, L-Box, U-Box and V-funnel tests were conducted as per EFNARC specifications. Table 4 gives the acceptance criteria for SCC. Table 5 gives the results of the tests conducted on the fresh SCC mixes for M25 grade.

Table 4. SCC - Acceptance Criteria as per EFNARC.

\begin{tabular}{lll}
\hline Test & Property & Range of values \\
\hline T50 Slump flow & Filling ability & $2-5 \mathrm{sec}$ \\
Slump Flow & Filling ability & $650-800 \mathrm{~mm}$ \\
V- funnel & Viscosity & $6-12 \mathrm{sec}$ \\
L- box & Passing ability & $0.8-1.0$ \\
U- box & Passing ability & $0-30 \mathrm{~mm}$ \\
\hline
\end{tabular}

Table 5. Results of Fresh Properties of SCC mixes.

\begin{tabular}{llllll}
\hline \multirow{2}{*}{ Type of Test } & \multicolumn{6}{l}{ SCC Mix containing } \\
\cline { 2 - 6 } & $\begin{array}{l}\text { Fly } \\
\text { Ash }\end{array}$ & GGBS & $\begin{array}{l}\text { Silica } \\
\text { Fume }\end{array}$ & RHA & $\begin{array}{l}\text { Shell } \\
\text { Lime }\end{array}$ \\
\hline $\begin{array}{l}\text { T50 Slump flow } \\
\text { (sec) }\end{array}$ & 3.0 & 2.50 & 3.0 & 3.5 & 2.30 \\
Slump Flow (mm) & 710 & 712 & 700 & 720 & 680 \\
V- funnel $(\mathrm{sec})$ & 7.60 & 7.40 & 7.0 & 6.52 & 6.0 \\
L- box: $\mathrm{H}_{2} / \mathrm{H}_{1}$ & 0.89 & 0.90 & 0.91 & 0.86 & 0.92 \\
U- box: $\mathrm{H}_{2}-\mathrm{H}_{1}(\mathrm{~mm})$ & 20 & 21 & 22 & 18 & 25 \\
\hline
\end{tabular}

\subsection{Tests on Hardened SCC}

\subsubsection{Compressive Strength}

The concrete is tested for its compressive strength after curing for 7, 14 and 28 days. All tests were performed in accordance with the provisions of IS: 516-1959 [19]. The test results are tabulated in Table 6 .

Table 6. Compressive Strength of SCC Mixes in MPa.

\begin{tabular}{llll}
\hline \multirow{2}{*}{ SCC Mix containing } & \multicolumn{3}{l}{ Period of curing } \\
\cline { 2 - 4 } & 7 Days & 14 Days & 28 Days \\
\hline Fly Ash & 11.16 & 18.01 & 26.72 \\
GGBS & 27.77 & 30.52 & 34.44 \\
Silica Fume & 20.62 & 28.12 & 31.04 \\
RHA & 21.23 & 23.34 & 30.52 \\
Shell Lime & 12.25 & 20.06 & 28.78 \\
\hline
\end{tabular}

\subsubsection{Flexural Strength}

The concrete was cured for 7, 14 and 28 days and it was tested for its flexural strength. All tests were performed in accordance with the provisions of IS: 516-1959 [19]. The test results are listed in Table 7.

Table 7. Flexural Strength of SCC Mixes in MPa.

\begin{tabular}{llll}
\hline \multirow{2}{*}{ SCC Mix containing } & \multicolumn{3}{l}{ Period of curing } \\
\cline { 2 - 4 } & 7 Days & 14 Days & 28 Days \\
\hline Fly Ash & 3.53 & 4.52 & 4.68 \\
GGBS & 3.92 & 4.82 & 5.34 \\
Silica Fume & 3.83 & 4.39 & 5.34 \\
RHA & 3.92 & 4.28 & 4.31 \\
Shell Lime & 3.84 & 4.16 & 4.87 \\
\hline
\end{tabular}

\subsubsection{Split Tensile Strength}

The concrete was tested for its split tensile strength after curing for 7, 14 and 28 days. All tests were performed in accordance with the provisions of IS: 5816-1999[20]. The test results are tabulated in Table 8 .

Table 8. Split Tensile Strength of SCC Mixes in MPa.

\begin{tabular}{llll}
\hline \multirow{2}{*}{ SCC Mix containing } & \multicolumn{3}{l}{ Period of curing } \\
\cline { 2 - 4 } & 7 Days & 14 Days & 28 Days \\
\hline Fly Ash & 1.63 & 1.70 & 2.49 \\
GGBS & 2.05 & 2.15 & 2.57 \\
Silica Fume & 1.83 & 1.99 & 2.49 \\
RHA & 1.56 & 1.79 & 2.53 \\
Shell Lime & 1.58 & 1.89 & 2.51 \\
\hline
\end{tabular}

\section{Results and Discussions}

\subsection{Mix Design}

In the Modified Nan Su method of mix proportioning of SCC, the quantity of the powder used in the concrete is mainly dependent on the consistency and the specific gravity of the powder itself. It can be observed from Table 2 that both specific gravity and consistency of GGBS and Shell lime powder are more, hence the requirement of GGBS and Shell lime is more when compared to that of other powders in their respective mixes, which can be observed in Table 3. Since the consistency of Silica Fume is more the quantity of its requirement is less.

Fig. 1 through Fig. 3 shows the variation of the hardened properties of the mixes with the age at curing.

\subsection{Compressive Strength}

From the results of compressive strength on hardened concrete, it is evident that the SCC mix containing GGBS has more strength as compared to the mixes containing other powders for curing days of 7 days, 14 days and 28 days. It is evident from the Table 6 that the compressive strength of SCC mix containing GGBS is $28.89 \%, 10.95 \%$, $12.84 \%$ and $19.66 \%$ more than that of SCC mixes containing fly ash, silica fume, RHA and shell lime powder respectively for a curing period of 28 days. 


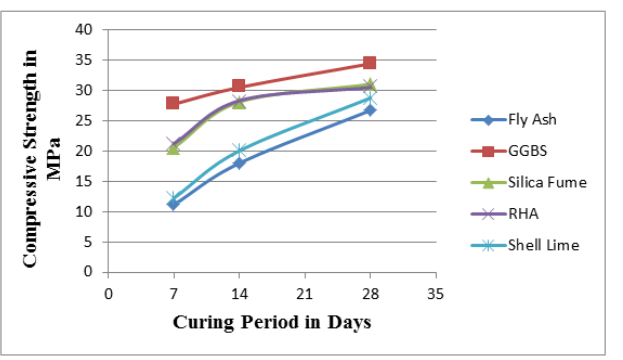

Figure 1. Variation of Compressive Strength with Curing Period.

\subsection{Flexural Strength}

Table 7 presents the test results carried out on hardened concrete for flexural strength. It is clear from the table that the flexural strength of SCC mix containing GGBS is more than that of SCC mixes containing other powders. The flexural strength of SCC mix containing GGBS is $9.87 \%$, $17.36 \%, 23.89 \%$ and $9.65 \%$ more than that of SCC mixes containing fly ash, silica fume, RHA and shell lime powder respectively for a curing period of 28 days.

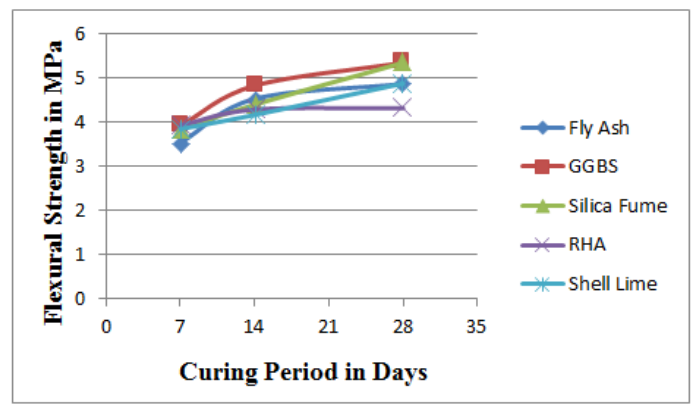

Figure 2. Variation of Flexural Strength with Curing Period.

\subsection{Split Tensile Strength}

Table 8 presents the test results carried out on hardened concrete for split tensile strength. It is clear from the table that the split tensile strength of the SCC mix containing GGBS is more than that of SCC mixes containing other powders. The split tensile strength of SCC mix containing GGBS is $3.21 \%$ more than that of SCC mixes containing fly ash and silica fume, and it is $1.55 \%$ and $2.40 \%$ more than that of SCC mixes containing RHA and shell lime powder respectively for a curing period of 28 days.

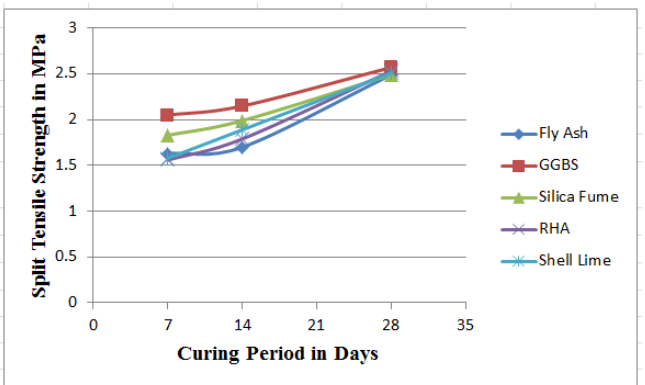

Figure 3. Variation of Split Tensile Strength with Curing Period.

\section{Conclusions}

The following conclusions can be made from the experimental study of achieving SCC using different mineral admixtures as filler:

- In the Modified Nan Su method of developing SCC, the quantity of the powder mainly depends on the specific gravity and consistency of the powder itself.

- The SCC mix containing GGBS exhibiting greater strength could be because of the high pozzolonic activity of GGBS.

- The slow strength gain in SCC mix containing Fly Ash is because the fly ash possibly requires more time for accelerating its pozzolonic nature.

- The strength of SCC mix containing silica fume is possibly due to silica fume providing micro filler effect, and also the quantity of silica fume is less which makes the mix richer in cement content, which imparts more strength.

- The silicates chain present in RHA helps the strength gain in SCC mix containing RHA as powder.

- The shell lime consists of calcium oxide, which possibly is the reason for the strength gain in SCC containing shell lime.

\section{References}

[1] Bouzoubaa N., Lachemi M., "Self Compacting Concrete Incorporating High-Volumes of Class F Fly Ash: Preliminary Results", Cement and Concrete Research, 2001, pp: 413-420.

[2] Kishor S. Sable, Madhuri K. Rathi, "Effect of different type of steel fiber and aspect ratio on mechanical properties of self-compacting concrete", International Journal of Engineering and Innovative Technology,2012,vol:2,1,pp 184-188.

[3] Nehdi M., Pardhan M., Khoshowski S., "Durability of self-compacting concrete incorporating high volume replacement composite cements", Cement and Concrete Research,2004,vol:34(11),pp:2103-2112.

[4] HemanthSood, Khitoliya R.K., Pathak S.S, "Incorporating European Standard for Testing Self Compacting Concrete in Indian Conditions", International Journal of Recent Trends in Engineering, 2009,vol:1,6,pp:41-45.

[5] Gaywala N.R, Raijiwala D.B, "Self compacting Concrete: A concrete of the decade", Journal of Engineering Research and Studies, 2011, Vol 2, pp:213-218.

[6] Ganesh Babu K., Sree Rama Kumar,'Efficiency of GGBS in concrete", Cement Concrete Research, 2000, Vol: 30(7), pp.1031-1036.

[7] Navaneethakrishnan A., Shanthi V.M,,"Experimental Study of Self Compacting Concrete using Silica Fume", International journal of Emerging Trends in Engineering and Development, 2012,vol:4(2), pp:475-482.

[8] Amir Juma, Rama Sai E., "A Review on Experimental Behavior of Self Compaction Concrete Incorporated with Rice Husk Ash", International Journal of science and advanced technology, Vol: 2, pp: 75-80. 
[9] B.H.V. Pai, Philip George, "Properties of Self Compacting concrete Containing Shell Lime Powder as Filler", International Journal of Engineering Research and development, 2013, vol: 9(6), pp: 62-68.

[10] Vilas V. Karjinni, Shrishail B. A., "Mixture proportion procedure for SCC", Indian Concrete Journal, June 2009, pp: $35-41$.

[11] IS: 8112- 1989.Specifications for 43 grade ordinary Portland cement. New Delhi, India: Bureau of Indian Standards.

[12] IS: 3812-1 2003. Specifications of pulverized fuel ash. New Delhi, India: Bureau of Indian Standards.

[13] IS: 12089-1987. Specification of Granulated slag for the manufacture of Portland Slag cement. New Delhi, India: Bureau of Indian Standards.

[14] IS: 15388-2003. Silica Fume - Specification. New Delhi, India: Bureau of Indian Standards.
[15] A. Juma, E. Rama Sai, "A Review on Experimental Behavior of Self Compaction Concrete Incorporated with Rice Husk Ash", International Journal of Science and Advanced Technology, 2(3), 2012,pp: 75-80.

[16] B.H.V.Pai, Pramukh Ganapathy. C, "Flexural Behaviour of Shell Lime Based Pre- stressed Self Compacting Concrete", International Journal of Engineering Research and Technology, Vol. 2, Dec 2013, pp: 3208- 3212.

[17] IS: 383-1970. Specifications for coarse and fine aggregates from natural sources for concrete. New Delhi, India: Bureau of Indian Standards.

[18] EFNARC, Specification and guidelines for Self Compacting Concrete, 2002, website: http://www.efnarc.org.

[19] IS: 516-1959. Methods of tests for strength of concrete. New Delhi, India: Bureau of Indian Standards.

[20] IS: 5816-1999.Splitting tensile strength of concrete -Methods. New Delhi, India: Bureau of Indian Standards. 